\title{
Polymorphisms of the angiotensin II type 1 receptor gene affect antihypertensive response to angiotensin receptor blockers in hypertensive Chinese
}

\author{
H.T. Gong', X.L. Ma ${ }^{2}$, B.X. Chen ${ }^{1}$, X.Y. Xu' ${ }^{1}$, Q. Li ${ }^{1}$, C.X. Guo ${ }^{1}$ and \\ F.H. Du ${ }^{1}$ \\ ${ }^{1}$ Department of Cardiology, Beijing Tiantan Hospital, \\ Capital University of Medical Science, Beijing, China \\ ${ }^{2}$ Department of Cardiology, Beijing Jian Gong Hospital, Beijing, China \\ Corresponding author: F.H. Du \\ E-mail: fhduu@yahoo.com.cn
}

Genet. Mol. Res. 12 (2): 2068-2075 (2013)

Received March 28, 2012

Accepted December 18, 2012

Published June 21, 2013

DOI http://dx.doi.org/10.4238/2013.June.21.2

\begin{abstract}
The renin-angiotensin-aldosterone system plays a key role in regulating blood pressure by maintaining vascular tone and the water/sodium balance. Many antihypertensive drugs target the reninangiotensin-aldosterone system, but the effect differs considerably among hypertensive patients. We investigated whether genetic variants of the angiotensin II type 1 receptor are associated with blood pressure response to angiotensin II receptor blockers in hypertensive Chinese patients. After a 2-week single-blind placebo run-in period, 148 patients with mild-to-moderate primary hypertension received monotherapy with $80 \mathrm{mg}$ /day telmisartan and then were followed up for 8 weeks. The $1166 \mathrm{~A} / \mathrm{C}, 573 \mathrm{~T} / \mathrm{C},-810 \mathrm{~A} / \mathrm{T}$, and $-521 \mathrm{C} / \mathrm{T}$ polymorphisms of the ATIR gene were determined through PCR and RFLP analysis. The relationship between these polymorphisms and changes in blood pressure was observed and evaluated after 8 weeks of treatment.
\end{abstract}


Patients with the AT1R -521CC genotype had a significant reduction in diastolic blood pressure compared to those carrying the $\mathrm{T}$ allele. No significant reduction in blood pressure was found in individuals with the $1166 \mathrm{~A} / \mathrm{C}, 573 \mathrm{~T} / \mathrm{C}$, or $-810 \mathrm{~A} / \mathrm{T}$ polymorphisms of the $A T 1 R$ gene. We conclude that only the AT1R -521CC genotype is associated with a significant decrease in blood pressure in response to telmisartan treatment in Chinese hypertensive patients.

Key words: Essential hypertension; Angiotensin II type 1 receptor; Single nucleotide polymorphism; Angiotensin receptor blocker

\section{INTRODUCTION}

Hypertension affects approximately one billion individuals worldwide and is a major risk factor for cardiovascular and cerebrovascular disease (Chobanian et al., 2003). Successful control of blood pressure could reduce the prevalence and incidence of myocardial infarction, stroke, heart failure, and renal disease. However, individual response to antihypertensive therapy is highly variable. Past efforts to identify responders to therapy include phenotypic (age, race) (Preston et al., 1998) and biochemical (renin profile, insulin sensitivity) factors (Laragh et al., 1988; Lind et al., 1995), but none of them revealed the value of extensive clinical utilization. Recent studies indicate that genetic variations may influence the clinical response to pharmacological treatment (Sciarrone et al., 2003; Filigheddu et al., 2004; Yu et al., 2006; Su et al., 2007).

The renin-angiotensin-aldosterone system is implicated in the pathogenesis of hypertension, cardiac hypertrophy and coronary heart disease. The major biologically active product of the renin-angiotensin system is angiotensin II, it plays important roles in normal physiology and in the progression of cardiac and renal diseases. Most of the effects of angiotensin II are mainly mediated by the angiotensin II type 1 receptor (AT1R), including vascular contraction, pressor responses, renal tubular sodium transport, and aldosterone secretion (Timmermans et al., 1993). The $A T 1 R$ gene has a length of over $55 \mathrm{~kb}$ and consists of 5 exons and 4 introns. Bonnardeaux et al. (1994) screened exon 5 and the 3 '-untranslated region (UTR) for mutations in 50 hypertensive subjects and identified several frequent polymorphisms, one of which, either an adenine $(\mathrm{A})$ or a cytosine $(\mathrm{C})$ base $(\mathrm{A} / \mathrm{C}$ transversion) at nucleotide position +1166 in the 3'-URT, was found to be associated with hypertension (Kikuya et al., 2003). Subsequent studies have examined the relation to arterial hypertension (Benetos et al., 1996), aortic stiffness (Nakauchi et al., 1996), myocardial infarction (Takami et al., 1998), hypertension-induced hypertrophy (Chapman et al., 2001), and carotid intimal-medial thickening (Miller et al., 1999). However, to date, whether or not there is a correlation between genetic variants of $A T 1 R$ and effects of antihypertensive drugs is really interesting but still unclear.

Our study aimed at evaluating the impact of $A T 1 R$ gene polymorphisms on the antihypertensive response in hypertensive patients receiving the angiotensin II receptor blocker telmisartan. Among the 4 variants, including $1166 \mathrm{~A} / \mathrm{C}$ and $573 \mathrm{~T} / \mathrm{C}$ in exon 5 as well as $-810 \mathrm{~A} /$ $\mathrm{T}$ and $-521 \mathrm{C} / \mathrm{T}$ in the promoter region, we found that in Chinese patients the -521CC genotype is the only one related to higher sensitivity to telmisartan treatment. 


\section{MATERIAL AND METHODS}

\section{Study subjects}

In this study, both male and female Chinese Han patients who met the following criteria were included: 18 to 80 years old; history of essential hypertension; diastolic blood pressure (DBP) from 90 to $109 \mathrm{mmHg}$; systolic blood pressure (SBP) from 140 to $179 \mathrm{mmHg}$. The exclusion criteria were as follows: secondary hypertension, congestive heart failure, cerebrovascular accident, myocardial infarction within the past 3 months; a documented history of unstable angina pectoris within the past 3 months; any clinically important abnormal laboratory findings, such as alanine aminotransferase (ALT) or creatinine level twice the upper limit of normal; pregnancy or lactation in women. The appropriate Ethics Committees approved this study. All of the participating patients gave informed consent before any study procedures.

\section{Study design}

Blood pressure (BP) was measured by a well-trained doctor or nurse using a mercury sphygmomanometer after the patient had rested for at least $10 \mathrm{~min}$ in a seated position and was determined as the mean of 3 measurements taken 2 min apart. A total of 164 patients were recruited with essential hypertension in our study. All antihypertensive agents were withdrawn before the start of a 2-week placebo period. At the end of the placebo period, 11 patients were excluded and a total of 153 qualified patients were given telmisartan, $80 \mathrm{mg}$ orally, once daily for 8 weeks. Five patients withdrew from the study because of failing to follow-up. Thus, 148 patients completed the 8-week trial, and their data were used for the present study. Blood was collected from all patients for genotype analysis.

\section{Definition of study variables}

Baseline information on the following variables was included in the analysis: gender, age, body mass index (BMI, $\left.\mathrm{kg} / \mathrm{m}^{2}\right), \mathrm{BP}$, heart rate. Laboratory variables included the serum levels of ALT, creatinine, glucose, uric acid, total cholesterol (TC), triglycerides (TG), high-density lipoprotein (HDL) and low-density lipoprotein (LDL), sodium, potassium and angiotensin II.

\section{Detection of $A T 1 R$ gene polymorphisms}

Genomic DNA was isolated from peripheral leukocytes separated from red blood cells according to the procedure of Tilzer et al. (1989). The ATIR polymorphisms were determined by PCR/RFLP. A 20- $\mu \mathrm{L}$ PCR reaction mixture contained 10X PCR buffer, $1.5 \mathrm{mM} \mathrm{MgCl}, 0.1$ $\mathrm{mM}$ of each dNTP, $0.5 \mu \mathrm{M}$ of each primer, $1 \mathrm{U}$ Taq enzyme (Takara), and $100 \mathrm{ng}$ genomic DNA. The primers for the 4 polymorphic sites are shown in Table 1 . The annealing temperatures of the 4 variant sites of PCR were set up differently as 1166 at $56^{\circ} \mathrm{C}, 573$ at $50^{\circ} \mathrm{C},-810$ at $58^{\circ} \mathrm{C}$, and -521 at $59^{\circ} \mathrm{C}$. After PCR amplification, restriction enzymes DdeI, Mn $1 \mathrm{I}, A l u \mathrm{I}$, and $S s p$ I (New England Biochemicals) were respectively applied to digest the PCR products for the 1166, 573, -810 , and -521 sites. The digested PCR products were then loaded on a $3 \%$ ethidium bromide-stained agarose gel to identify the product sizes. 


\begin{tabular}{llr}
\multicolumn{2}{c}{ Table 1. Primer sequences used for amplification of AT1R SNPs. } \\
\hline Polymorphism site & Primer sequence & Restriction enzyme \\
\hline 1166 & Forward: 5'-TCA TCC ACC AAG AAG CCT-3' & DdeI \\
573 & Reverse: 5'-TCC TGT TGC TCC TCT AAC G-3' & MnlI \\
& Forward: 5'-CTT GTA GCC AAA GTC ACC T-3' & AluI \\
-810 & Reverse: 5'-CGT GTC CAC AAT ATC TGC-3' & SspI \\
& Forward: 5'-CCA GAT AAA GAC ATC ACG AGA C-3' & \\
& Reverse: 5'-ACA GTC ACC CTA CTC ACC TAG C-3' & \\
\hline SNPS $=$ Fingle nucleotide polymord: 5'-CGA ACT TTG GTA ATA CAG TTG TGG-3' & Reverse: 5'-GAG TTG GGA GAT CAT CCT TAC TC-3'
\end{tabular}

\section{Statistical analysis}

Data are reported as means \pm standard deviation (SD). The $\chi^{2}$ test was used to evaluate categorical variables and test for Hardy-Weinberg equilibrium (HWE) of polymorphisms. Differences in biochemical parameters and BP were assessed using a paired $t$-test. Linear regression modeling was used to determine the correlation of BP response with genotypes, following normalization with pretreatment BP, age, gender, BMI, blood glucose, TC, TG, HDL, and LDL. The SPSS 11.5 software was applied for statistical analysis. A two-tailed P value less than 0.05 was considered to be significant.

\section{RESULTS}

\section{Characteristics of the study subject}

Data from the 148 patients were analyzed in this study. All patients had mildto-moderate hypertension. The basic characteristics of patients are presented in Table 2. After a 8-week treatment with telmisartan, both SBP and DBP were remarkably decreased $(\mathrm{P}<0.001)$. The serum angiotensin II level was obviously increased at the end of the 8 -week treatment $(\mathrm{P}<0.001)$. No significant differences were observed for the other parameters.

\section{Genotype and antihypertensive response to telmisartan}

Genotype and allele distributions of the study population are summarized in Table 3. Genotype and allele frequencies of each polymorphism in the study population were in HWE $(\mathrm{P}>0.05)$. The changes in BP response to antihypertensive treatment in relation to genotypes of AT1R gene polymorphisms are shown in Table 4. Five subjects carrying the homozygous $-521 \mathrm{~T}$ allele was found, so CT and TT genotypes were used in combination for analyses. We did not find any association of $A T 1 R 1166 \mathrm{~A} / \mathrm{C}, 573 \mathrm{~T} / \mathrm{C}$, and $-810 \mathrm{~A} / \mathrm{T}$ polymorphisms with SBP or DBP response to telmisartan. Surprisingly, linear regression analysis indicated that only $A T 1 R-521 \mathrm{C} / \mathrm{T}$ was associated with DBP response to telmisartan, after correction with covariates, including pretreatment DBP, age, gender, BMI, blood glucose, TC, TG, HDL, and LDL $(\mathrm{P}=0.039)$. ATIR $-521 \mathrm{C} / \mathrm{T}$ accounted for $17.7 \%$ of interindividual variation in the DBP response to telmisartan. The patients carrying the $-521 \mathrm{CC}$ genotype showed a greater reduction in DBP than those carrying the T allele (CT+TT) (Figure 1). 
Table 2. Changes of patient characteristics and blood pressure response to the treatment.

\begin{tabular}{|c|c|c|c|}
\hline Characteristic & Pretreatment & Post-treatment & $\mathrm{P}$ \\
\hline BMI $\left(\mathrm{kg} / \mathrm{m}^{2}\right)$ & $25.8 \pm 3.5$ & $25.7 \pm 3.3$ & 0.562 \\
\hline SBP (mmHg) & $159.5 \pm 16.4$ & $145.4 \pm 20$ & $<0.001$ \\
\hline DBP (mmHg) & $101.5 \pm 7.1$ & $93.4 \pm 10$ & $<0.001$ \\
\hline HR (bpm) & $68.45 \pm 10.85$ & $68.23 \pm 9.27$ & 0.786 \\
\hline $\operatorname{ALT}(\mathrm{U} / \mathrm{L})$ & $24.33 \pm 12.17$ & $24.25 \pm 12.73$ & 0.938 \\
\hline AST (U/L) & $25.98 \pm 10.69$ & $24.65 \pm 10.92$ & 0.340 \\
\hline $\mathrm{Cr}(\mathrm{mg} / \mathrm{dL})$ & $61.15 \pm 12.42$ & $60.01 \pm 12.72$ & 0.209 \\
\hline BUN (mM) & $5.55 \pm 1.72$ & $5.71 \pm 1.78$ & 0.314 \\
\hline $\mathrm{UA}(\mu \mathrm{M})$ & $264.54 \pm 83.79$ & $256.43 \pm 78.23$ & 0.256 \\
\hline Glu (mM) & $5.44 \pm 1.69$ & $5.32 \pm 1.65$ & 0.398 \\
\hline $\mathrm{TC}(\mathrm{mM})$ & $4.67 \pm 0.91$ & $4.70 \pm 0.91$ & 0.636 \\
\hline $\mathrm{TG}(\mathrm{mM})$ & $1.67 \pm 1.0$ & $1.56 \pm 1.2$ & 0.165 \\
\hline LDL (mM) & $2.73 \pm 0.78$ & $2.74 \pm 0.74$ & 0.875 \\
\hline HDL (mM) & $1.34 \pm 0.38$ & $1.36 \pm 0.38$ & 0.260 \\
\hline $\mathrm{Na}^{+}(\mathrm{mM})$ & $141.38 \pm 2.96$ & $140.99 \pm 2.49$ & 0.230 \\
\hline $\mathrm{K}^{+}(\mathrm{mM})$ & $4.03 \pm 0.42$ & $4.10 \pm 0.51$ & 0.093 \\
\hline $\mathrm{Cl}^{-}(\mathrm{mM})$ & $102.98 \pm 2.42$ & $102.47 \pm 2.46$ & 0.068 \\
\hline Ang II (pg/mL) & $76.3 \pm 56.6$ & $107.0 \pm 66.7$ & $<0.001$ \\
\hline
\end{tabular}

Data are reported as means \pm SD. The P value was calculated by the paired-samples $t$-test. BMI = body mass index; $\mathrm{SBP}=$ systolic blood pressure; $\mathrm{DBP}=$ diastolic blood pressure; $\mathrm{HR}=$ heart rate; $\mathrm{ALT}=$ alanine aminotransferase; $\mathrm{AST}=$ aspartate aminotransferase; $\mathrm{Cr}=$ creatinine; $\mathrm{BUN}=$ blood urea nitrogen; $\mathrm{UA}=$ uric acid; $\mathrm{Glu}=$ glucose; $\mathrm{TC}=$ total cholesterol; $\mathrm{TG}=$ triglyceride $\mathrm{LDL}=$ low-density lipoprotein; $\mathrm{HDL}=$ high-density lipoprotein; $\mathrm{Na}^{+}=$ sodium ion; $\mathrm{K}^{+}=$potassium ion; $\mathrm{Cl}^{-}=$chloride ion; Ang II = angiotensin II.

Table 3. Genotype and allele frequencies of the $1166 \mathrm{~A} / \mathrm{C}, 573 \mathrm{~T} / \mathrm{C},-810 \mathrm{~A} / \mathrm{T}$, and $-521 \mathrm{C} / \mathrm{T}$ polymorphisms of the $A T 1 R$ gene in the study population.

\begin{tabular}{|c|c|c|c|c|c|}
\hline \multirow{2}{*}{$\frac{\text { Polymorphism }}{1166 \mathrm{~A} / \mathrm{C}}$} & \multicolumn{3}{|c|}{ Genotype } & \multicolumn{2}{|c|}{ Allele frequency } \\
\hline & AA & $\mathrm{AC}$ & $\mathrm{CC}$ & $\mathrm{A}$ & $\mathrm{C}$ \\
\hline & $126(85.1)$ & $22(14.9)$ & $0(0 \%)$ & $274(92.6 \%)$ & $22(7.4 \%)$ \\
\hline \multirow[t]{2}{*}{$573 \mathrm{~T} / \mathrm{C}$} & TT & $\mathrm{TC}$ & $\mathrm{CC}$ & $\mathrm{T}$ & $\mathrm{C}$ \\
\hline & $76(51.3 \%)$ & $59(39.9 \%)$ & $13(8.8 \%)$ & $211(71.3 \%)$ & $85(28.7 \%)$ \\
\hline \multirow{2}{*}{$-810 \mathrm{~A} / \mathrm{T}$} & AA & AT & TT & A & $\mathrm{T}$ \\
\hline & $81(54.7 \%)$ & $50(33.8 \%)$ & $17(11.5 \%)$ & $212(71.6 \%)$ & $84(28.4 \%)$ \\
\hline \multirow[t]{2}{*}{$-521 \mathrm{C} / \mathrm{T}$} & $\mathrm{CC}$ & $\mathrm{CT}$ & TT & $\mathrm{C}$ & $\mathrm{T}$ \\
\hline & $91(60.8 \%)$ & $52(35.8 \%)$ & $5(3.4 \%)$ & $233(78.7 \%)$ & $63(21.3 \%)$ \\
\hline
\end{tabular}

Table 4. SNPs of the $A T 1 R$ gene in linear regression and blood pressure (BP) response to antihypertensive drugs.

\begin{tabular}{|c|c|c|c|c|c|c|c|}
\hline \multirow[t]{2}{*}{ Genotype } & \multirow[t]{2}{*}{ Predictors in model } & \multicolumn{3}{|c|}{ Systolic BP response } & \multicolumn{3}{|c|}{ Diastolic BP response } \\
\hline & & Standardized $\beta$ & $\mathrm{P}$ & $\mathrm{R}^{2}$ & Standardized $\beta$ & $P$ & $\mathrm{R}^{2}$ \\
\hline \multirow[t]{2}{*}{$1166 \mathrm{~A} / \mathrm{C} \mathrm{AA}, \mathrm{AC}$} & Alone & 0.111 & 0.271 & 0.012 & 0.093 & 0.356 & 0.009 \\
\hline & After covariates & 0.100 & 0.344 & 0.094 & 0.084 & 0.415 & 0.144 \\
\hline \multirow[t]{2}{*}{ 573T/C TT, TC, CC } & Alone & 0.059 & 0.561 & 0.003 & 0.077 & 0.448 & 0.006 \\
\hline & After covariates & -0.001 & 0.994 & 0.084 & 0.009 & 0.933 & 0.138 \\
\hline \multirow[t]{2}{*}{$-810 \mathrm{~A} / \mathrm{T}$ AA, AT, TT } & Alone & -0.032 & 0.751 & 0.001 & -0.031 & 0.758 & 0.001 \\
\hline & After covariates & -0.010 & 0.924 & 0.084 & -0.024 & 0.816 & 0.138 \\
\hline \multirow[t]{2}{*}{$-521 \mathrm{C} / \mathrm{T} \mathrm{CC}, \mathrm{CT}+\mathrm{TT}$} & Alone & 0.025 & 0.809 & 0.001 & 0.224 & 0.025 & 0.05 \\
\hline & After covariates & 0.031 & 0.782 & 0.09 & 0.22 & 0.035 & 0.177 \\
\hline
\end{tabular}

Four SNPs were first considered by themselves (alone) as a predictor of the BP response, then after adjustment for the concomitant variables including pretreatment BP, age, gender, BMI, glucose, TG, TC, HDL, and LDL (after covariates). Standardized $\beta$ is the standardized regression coefficient; $\mathrm{R}^{2}$ is the percentage of interindividual variation in BP response explained by predictors in the model. 


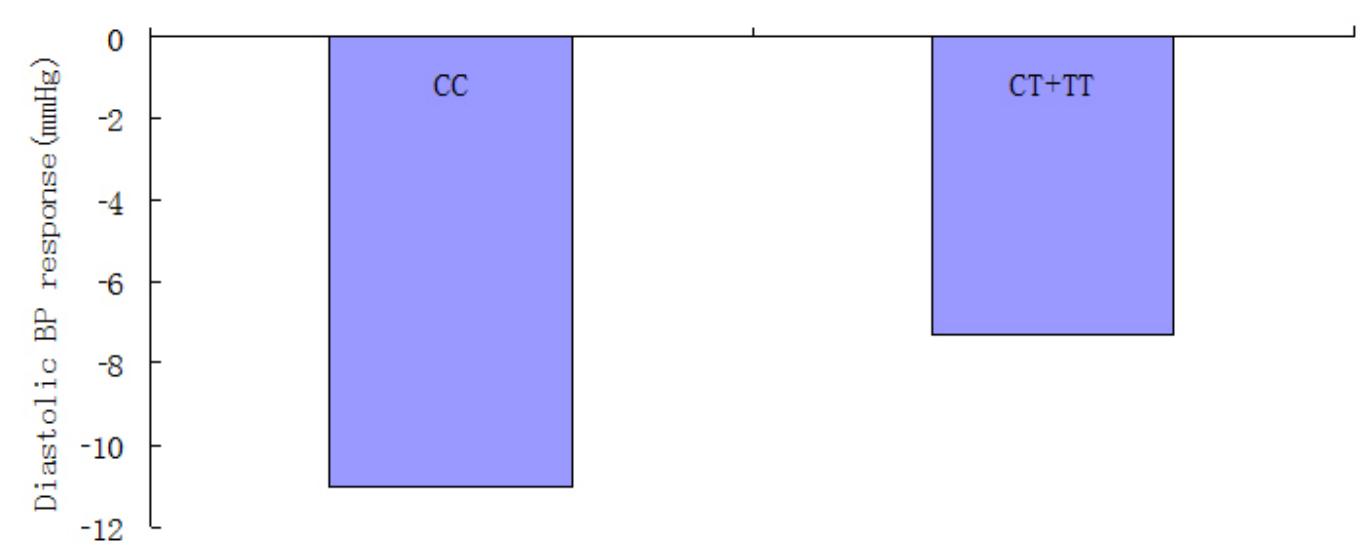

Figure 1. Diastolic blood pressure (BP) response to telmisartan based on $-521 \mathrm{C} / \mathrm{T}$ genotypes after adjustment for pretreatment DBP, age, gender, BMI, glucose, TG, TC, HDL, and LDL.

\section{DISCUSSION}

$A T 1 R-521 \mathrm{C} / \mathrm{T}$ is localized in the promoter region. It is unclear whether hypertension or antihypertensive drug effect is associated with polymorphisms in the promoter of the $A T 1 R$ gene. Erdamann et al. (1999) characterized 9 sequence variants located in the functional promoter region of the $A T 1 R$ gene, which may have the potential to influence $A T 1 R$ gene expression. Moreover, 7 of these variants were found to be completely linked, such that the analysis of 3 single nucleotide polymorphism (SNPs) should provide information for all possible haplotypes. The ECTIM study indicated that the $-810 \mathrm{~A} / \mathrm{T}$ polymorphism may be associated with the risk of myocardial infarction in males (Poirier et al., 1998). Moreover, among 6 SNPs discovered in the promoter region of the $A T 1 R$ gene, Jin et al. (2003) found that the $-810 \mathrm{~A} / \mathrm{T}$ is almost in complete linkage disequilibrium with 4 other SNPs $(-713 \mathrm{G} / \mathrm{T},-214 \mathrm{~A} / \mathrm{C},-213 \mathrm{G} / \mathrm{C}$, and $-153 \mathrm{~A} / \mathrm{G}$ ) and the $-810 \mathrm{~A} / \mathrm{T}$ polymorphism is a genetic risk factor for essential hypertension complicated with coronary heart disease. Until now, little is known about the association between polymorphisms in the promoter of the $A T 1 R$ gene and blood pressure response to antihypertensive treatment. We genotyped the 2 polymorphic sites $-810 \mathrm{~A} / \mathrm{T}$ and $-521 \mathrm{C} / \mathrm{T}$, which do not exist in linkage disequilibrium, and found $A T 1 R-521 \mathrm{C} / \mathrm{T}$ associated with blood pressure responses. In this study, we revealed that the $A T 1 R-521 \mathrm{C} / \mathrm{T}$ polymorphism was associated with BP response to antihypertensive drug. After a 8-week telmisartan treatment, patients carrying the $-521 \mathrm{CC}$ genotype showed a greater reduction in DBP than those carrying the $\mathrm{T}$ allele. The association remained after adjustment for multiple comparisons as well as for potential confounding factors including baseline BP. To our knowledge, our study is the first to prove that the $-521 \mathrm{C} / \mathrm{T}$ variation is associated with an antihypertensive effect.

At present, the $1166 \mathrm{~A} / \mathrm{C}$ polymorphism is the best evaluated. This polymorphism is located in an untranslated region of the gene, but may be in linkage disequilibrium with a functional variant, which could affect the regulation of the gene in response to Ang II. Miller et al. (1999) hypothesized that renal and systemic angiotensin II activity would be augmented in subjects with the $\mathrm{C}$ allele of the $A T 1 R$ gene $+1166 \mathrm{~A} / \mathrm{C}$ polymorphism, and tested this hypoth- 
esis by comparing hemodynamic and humoral responses to $A T 1 R$ blockade with losartan and with low-dose suppressor infusion of angiotensin II (Guo et al., 1994). In this study, losartan increased the glomerular filtration rate and decreased mean arterial blood pressure in subjects with the $\mathrm{C}$ allele. Kurland et al. (2001) did not show relationships between $A G T$ M235T or $A T 1 R$ A1166C polymorphism and response to treatment for 3 months with irbesartan or atenolol, whereas the ACE I/D genotype predicted the blood-lowering response to these antihypertensive therapies. In our study, there was a tendency for a greater SBP reduction in patients carrying the $\mathrm{C}$ allele compared with those carrying the $\mathrm{T}$ allele after treatment, but it did not reach statistical significance (data not shown). One possible explanation for the result is that relatively small numbers of subjects were included in this study. There were also no significant differences between the 2 genotype groups in angiotensin II level before and after treatment.

Another SNP also has been described in which there is either a thymine (T) or a cytosine (C) base $(\mathrm{C} / \mathrm{T}$ transversion) in nucleotide position 573 in exon 5 . The presence of the $\mathrm{T} 573 \mathrm{C}$ polymorphism of the $A T 1 R$ gene has been associated with hypertension and diabetes (Doria et al., 1997; Chaves et al., 2001). Chaves et al. (2001) found that the T573C polymorphism may be a genetic protective factor for urinary albumin excretion in a population of essential hypertensive patients. However, Redon et al. (2005) found that neither blood pressure response nor the rate of urinary albumin excretion had any relationship with the presence of the $\mathrm{T} 573 \mathrm{C}$ polymorphism while on telmisartan therapy. Our present results are consistent with the above findings.

The limitation of our study is the focus on only a lowering of BP. We recognize that for long-term clinical outcomes (coronary heart disease, stroke, chronic kidney disease) it may be more important to elucidate individual gene-drug interactions on end points in a clinical setting. Outcome-based research may result in more effective BP control and a lower incidence of hypertension-related morbidity and mortality (Psaty et al., 2002; Bis et al., 2003). We plan to use this approach to study the outcomes and antihypertensive treatment in the future.

\section{ACKNOWLEDGMENTS}

Research supported by the Sino-German Laboratory for Molecular Medicine, FuWai Cardiovascular Hospital and Cardiovascular Institute, China.

\section{REFERENCES}

Benetos A, Gautier S, Ricard S, Topouchian J, et al. (1996). Influence of angiotensin-converting enzyme and angiotensin II type 1 receptor gene polymorphisms on aortic stiffness in normotensive and hypertensive patients. Circulation 94: 698-703.

Bis JC, Smith NL, Psaty BM, Heckbert SR, et al. (2003). Angiotensinogen Met235Thr polymorphism, angiotensinconverting enzyme inhibitor therapy, and the risk of nonfatal stroke or myocardial infarction in hypertensive patients. Am. J. Hypertens. 16: 1011-1017.

Bonnardeaux A, Davies E, Jeunemaitre X, Fery I, et al. (1994). Angiotensin II type 1 receptor gene polymorphisms in human essential hypertension. Hypertension 24: 63-69.

Chapman CM, Palmer LJ, McQuillan BM, Hung J, et al. (2001). Polymorphisms in the angiotensinogen gene are associated with carotid intimal-medial thickening in females from a community-based population. Atherosclerosis 159: 209-217.

Chaves FJ, Pascual JM, Rovira E, Armengod ME, et al. (2001). Angiotensin II AT1 receptor gene polymorphism and microalbuminuria in essential hypertension. Am. J. Hypertens. 14: 364-370.

Chobanian AV, Bakris GL, Black HR, Cushman WC, et al. (2003). The Seventh Report of the Joint National Committee on Prevention, Detection, Evaluation, and Treatment of High Blood Pressure: The JNC 7 Report. JAMA 289: 2560-2572.

Doria A, Onuma T, Warram JH and Krolewski AS (1997). Synergistic effect of angiotensin II type 1 receptor genotype 
and poor glycaemic control on risk of nephropathy in IDDM. Diabetologia 40: 1293-1299.

Erdmann J, Riedel K, Rohde K, Folgmann I, et al. (1999). Characterization of polymorphisms in the promoter of the human angiotensin II subtype 1 (AT1) receptor gene. Ann. Hum. Genet. 63: 369-374.

Filigheddu F, Reid JE, Troffa C, PinnaParpaglia P, et al. (2004). Genetic polymorphisms of the beta-adrenergic system: association with essential hypertension and response to beta-blockade. Pharmacogenomics J. 4: 154-160.

Guo DF, Furuta H, Mizukoshi M and Inagami T (1994). The genomic organization of human angiotensin II type 1 receptor. Biochem. Biophys. Res. Commun. 200: 313-319.

Jin W, Liu Y, Sheng HH, Jin L, et al. (2003). Single nucleotide polymorphisms in promoter of angiotensin II type 1 receptor gene associated with essential hypertension and coronary heart disease in Chinese population. Acta Pharmacol. Sin. 24: 1083-1088.

Kikuya M, Sugimoto K, Katsuya T, Suzuki M, et al. (2003). A/C1166 gene polymorphism of the angiotensin II type 1 receptor (AT1) and ambulatory blood pressure: the Ohasama Study. Hypertens. Res. 26: 141-145.

Kurland L, Melhus H, Karlsson J, Kahan T, et al. (2001). Angiotensin converting enzyme gene polymorphism predicts blood pressure response to angiotensin II receptor type 1 antagonist treatment in hypertensive patients. J. Hypertens. 19: 1783-1787.

Laragh JH, Lamport B, Sealey J and Alderman MH (1988). Diagnosis ex juvantibus. Individual response patterns to drugs reveal hypertension mechanisms and simplify treatment. Hypertension 12: 223-226.

Lind L, Berne C, Andersson PE, Hanni A, et al. (1995). Is insulin resistance a predictor of the blood pressure response to anti-hypertensive treatment? J. Hum. Hypertens. 9: 759-763.

Miller JA, Thai K and Scholey JW (1999). Angiotensin II type 1 receptor gene polymorphism predicts response to losartan and angiotensin II. Kidney Int. 56: 2173-2180.

Nakauchi Y, Suehiro T, Yamamoto M, Yasuoka N, et al. (1996). Significance of angiotensin I-converting enzyme and angiotensin II type 1 receptor gene polymorphisms as risk factors for coronary heart disease. Atherosclerosis 125: 161-169.

Poirier O, Georges JL, Ricard S, Arveiler D, et al. (1998). New polymorphisms of the angiotensin II type 1 receptor gene and their associations with myocardial infarction and blood pressure: the ECTIM study. Etude Cas-Temoin de l'Infarctus du Myocarde. J. Hypertens. 16: 1443-1447.

Preston RA, Materson BJ, Reda DJ, Williams DW, et al. (1998). Age-race subgroup compared with renin profile as predictors of blood pressure response to antihypertensive therapy. Department of Veterans Affairs Cooperative Study Group on Antihypertensive Agents. JAMA 280: 1168-1172.

Psaty BM, Smith NL, Heckbert SR, Vos HL, et al. (2002). Diuretic therapy, the alpha-adducin gene variant, and the risk of myocardial infarction or stroke in persons with treated hypertension. JAMA 287: 1680-1689.

Redon J, Luque-Otero M, Martell N and Chaves FJ (2005). Renin-angiotensin system gene polymorphisms: relationship with blood pressure and microalbuminuria in telmisartan-treated hypertensive patients. Pharmacogenomics J. 5: 14-20.

Sciarrone MT, Stella P, Barlassina C, Manunta P, et al. (2003). ACE and $\alpha$-adducin polymorphism as markers of individual response to diuretic therapy. Hypertension 41: 398-403.

Su X, Lee L, Li X, Lv J, et al. (2007). Association between angiotensinogen, angiotensin II receptor genes, and blood pressure response to an angiotensin-converting enzyme inhibitor. Circulation 115: 725-732.

Takami S, Katsuya T, Rakugi H, Sato N, et al. (1998). Angiotensin II type 1 receptor gene polymorphism is associated with increase of left ventricular mass but not with hypertension. Am. J. Hypertens. 11: 316-321.

Tilzer L, Thomas S and Moreno RF (1989). Use of silica gel polymer for DNA extraction with organic solvents. Anal. Biochem. 183: 13-15.

Timmermans PB, Wong PC, Chiu AT, Herblin WF, et al. (1993). Angiotensin II receptors and angiotensin II receptor antagonists. Pharmacol. Rev. 45: 205-251.

Yu HM, Lin SG, Liu GZ, Zhang YQ, et al. (2006). Associations between CYP11B2 gene polymorphisms and the response to angiotensin-converting enzyme inhibitors. Clin. Pharmacol. Ther. 79: 581-589. 